\title{
Pedagogical workshops and the problem-based approach as interdisciplinary strategy: an experience in higher education
}

DOI: $10.46932 /$ sfjdv2n2-077

Received in: March 1st, 2021

Accepted in: May 30th, 2021

\author{
Marineuza Matos dos Anjos ${ }^{1}$ \\ Departamento de Educação - Campus I - Universidade do Estado da Bahia - Brasil \\ E- mail:mmanjos@uneb.br
}

\begin{abstract}
Contemporary teacher training education reflects the specter of an education that today is guided by the demands placed in the context of a globalized economy. The logic of teaching in higher education curricula is still found, often guided by obsolete pedagogical practices. As the current paradigms are sometimes not enough to think about formation, it is necessary to analyze through another bias. Therefore, one should reflect not only on the prism of the theoretical contributions offered by scientific and technological knowledge; but in a way that also encompasses contributions from other fields such as Pedagogy, Sociology and Philosophy. With this perspective in mind, the research presents a structured teaching experience in the Problem Based Approach (PBA) and in the use of Pedagogical Workshops. The investigation took place at the Bahia State University (UNEB- Brazil) in the Pedagogy Course. The objectives were: 1) the proposition of learning situations that promote the active participation of students in solving real and everyday problems; 2) the combination of individual and group work; 3) the discussion of contents and how to approach them in an interdisciplinary way; and 4) arouse interest in attitudes of investigation, action, reflection, appreciation, and evaluation. The work portrays an experience analysis based on qualitative methods and uses as data collection the records in class diaries and the application of open questionnaires.
\end{abstract}

Keywords: Interdisciplinarity. Pedagogical Workshops. Problem Based Approach.

\section{INTRODUCTION}

Education inserted in a context permeated by uncertainties, dehumanization processes generated by profit-based economic policies, makes us face complex contemporary issues, local and global. Reflecting educational methods in a direction that includes philosophical as well as scientific and technological aspects can be a way to help higher education teachers to reflect on the real meaning of their pedagogical actions and to build a sense of formation grounded in dialogue with the areas of knowledge and the production of meanings that qualify educational practices.

\footnotetext{
${ }^{1}$ Doutora em Difusão do Conhecimento pelo Programa de Doutorado Multi-institucional e Multidisciplinar em Difusão do Conhecimento da Universidade Federal da Bahia - UFBA; Estágio Doutoral na Faculdade de Psicologia e Ciências da Educação na Universidade de Coimbra - Portugal; Professora Assistente do Departamento de Educação da Universidade do Estado da Bahia - UNEB; Mestre em Produção Aquática. Especialista em Filosofia Contemporânea pela Faculdade São Bento da Bahia. Licenciada em Ciências Biológicas pela Universidade Federal da Bahia - UFBA.
} 
In this sense, would be the realization of Pedagogical Workshops embodied in the Problem Based Approach (PBA), a horizon to offer an interdisciplinary understanding capable of attributing a very significant methodological theoretical contribution to teacher education? Training future teachers in this line of thinking requires an approach that goes beyond disciplinarity or multidisciplinarity, it is necessary the contribution of elements of other knowledge that account for the complexity of training as a field of research and knowledge.

The promotion of this dialogue from a critical, reflective, and investigative perspective can be a subsidy to understand the role of the subject and his insertion in this globalized world, the education system, and the new role that the teacher plays in the midst of these transformations. This interdisciplinary proposal presents an analysis of teaching experience, developed at the Bahia State University (UNEB Brazil). Its objectives are: 1) provide learning situations that promote students' active participation in solving real and everyday problems; 2) enable the combination of individual and group work; 3) discuss the contents and how to approach them in an interdisciplinary way; and 4) arouse interest in attitudes of investigation, action, reflection, appreciation and evaluation.

The Problem-Based Learning method first arises at the Universities of MacMaster, Canada and Masstrich, The Netherlands (Lopez and Fernádez, 2015), with the purpose of allowing the student to become the subject of his own learning environment, to be responsible by choosing the teaching materials, defining the sequence of their learning and participating in the assessment modes.

Problem-based learning (PBL) "is a didactic system that requires students to actively engage in their own learning to the point of defining a self-directed learning setting” (Moya, 2015, p.19). The choice for this type of methodology represents a possible way for the development of skills necessary for the formation of active subjects in the construction of knowledge and their autonomy.

In contemporary times, the challenge is to think of an education that allows the development of an individual autonomy but embodied in a perspective of confluence with the collective. In this sense, it is important to glimpse the construction of knowledge in networks, in an interdependent and interdisciplinary way. PBL, if worked on the whole vision, with the contribution of different areas of knowledge, can critically and reflexively enable an innovative, ethical and transformative pedagogical practice. Since it is a method capable of promoting integrated learning in which knowledge is related to the reflection of real issues arising from interaction with the environment, from the generated learning processes may give rise to new opportunities for reflection and stimulation to other learning.

Thus, integration occurs through the approximation of what with the how and what to learn, structuring factors for the pedagogical didactic processes. Motivation to learn, communication skills, and learning to work with others in a cooperative, teacher-managed work environment are, in Moya's view, 
learning dimensions that represent very significant gains when developing activities in the method approach of the PBL.

Pedagogical Workshops associated with PBL represent a strategy capable of enhancing the teaching and learning modes through the exchange of knowledge and experiences between teachers and students; both have in themselves the relationship with the possibility of collaborative learning. According to Anjos,

The workshop is a different and creative way of dealing with the organization of teaching; It represents a valuable pedagogical instrument capable of stimulating teaching and learning and stimulating the effective participation of its members; enable the individual and collective construction of knowledge, the confrontation and exchange of ideas and experiences in a dialogical perspective of understanding in a multifaceted way of reality (Anjos, 2017).

It is a strategy that goes beyond a simple way of preparing the class and seeks, at all times, to question the way knowledge is produced, operationalized and socialized in formal and informal daily action, at school and out of school, in life of thousands of students and teachers. When combined with problem solving, it is possible to understand situations in which reality interacts with the environment, cognitive conflicts arising from new problem situations stimulate learning, thus enhancing the development of skills and the construction of new knowledge.

Therefore, training future teachers in this understanding requires an approach of assumptions that communes with a theoretical support from the scientific, pedagogical and philosophical knowledge, which seeks the look of complexity and reflects on formation proposals that break with the culture of reproduction practices and repetition walking the paths of an understanding of teaching that leads to proposition and problem solving, so that it potentiates rather than weakens it; that privileges a new vision of education fostersing, this way the transformation and human development. It is necessary to treat formation through a bias of teaching by research and by the reflection of ethical values, in a systemic, integrative perspective, of the diffusion of knowledge and of the formative processes; from this point of view, powerful insights can be offered for reflective practice and training.

Ethics as a constitutive element of the formation of being is present in the daily actions of subjects of any society, in any temporality independent of the structure, organization and diversity that establishes the culture of a society. Based this point of view, it is necessary to understand the ways in which each civilization deals with the ethical questions that support each one, and the dilemmas they face, the way the subjects interact and guide their ways of being in the world. Relations between people are marked by norms of conduct and rules that govern the individual and collective behavior of individuals and allow coexistence in community through social and cultural interactions between the subjects and between the subjects and the environment. 
The field of education plays a fundamental role in this process; the ethics have as their main objective the preservation of the human essence. The teachers deal with complex daily issues, especially in the interpersonal relationships with the learning subjects. Teaching actions permeate diverse responsibilities that go beyond the act of teaching, actions that their deployment can bring consequences in their application and require a posture of responsibility before the countless possibilities that cannot always be calculated.

\section{RESEARCH ITINERARY}

This paper presents an interdisciplinary experience in Higher Education, developed in the discipline of Methodological Theoretical References of Natural Sciences Teaching for Elementary School, at the Bahia State University - UNEB - Brazil. It is an analysis based on qualitative methods and the records in class diaries and open questionnaires collected during collective planning are used as dates.

Understanding that dialogue in education cannot be imposing, but an interactive dialogue between teachers / students, it is presented to students a provisional work proposal to be reworked from their interventions during the work.

The Natural Sciences area, due to its constitution of different themes, coming from different fields of knowledge such as Biology, Physics, Chemistry, etc., allows an interdisciplinary and multi-referential approach enhancing a broad and complex perception of the phenomena under study. The multi-referential approach, in a position that fully assumes the hypothesis of complexity, and even of the hypercomplexity of reality, proposes a plural reading of its objects (practical or theoretical) from different points of view. This, Ardoino (1998, p.24) points out, "implies both specific views and languages appropriate to the descriptions required, depending on distinct reference systems". These systems are heterogeneous once they are "considered, explicitly recognized as not reducible to each other".

The idea of multi-referentiality in the perspective of Jaques Ardoino's thought is not focused on a reflection only about the Educational Sciences. According to Berger (2012, p.24), "the world of work, of social work practices as well as of health, is for Ardoino, as or more important than that of school”. From this perspective, Ardoino's concern was not to reflect on science linked to collective history, the notion of discipline, but rather to reflect on the notion of practice. And in its conception, the practice deeply marks the notion of multi-referentiality, more than a concept, it opens a horizon of possibilities for thinking about the complexity that surrounds teacher education and educational processes. "It presents itself as an epistemology, a way of seeing the world in which we operate; one way of understanding science, knowledge, the other, our own performance in the social and with ourselves. (Barbosa, 2012, p. 63-64). 
Thinking about teacher education in this aspect, critically and investigatively, can help overcome the fragmentation of thought in the construction of knowledge and enable a broader reflection of education and the processes that involve teaching and learning. It was in this line of understanding that teachers and students made no effort to find an effective way to plan, in a participatory way, an inspiration of interdisciplinary work that would allow the discussion of the subject contents through Pedagogical Workshops using the Problem Based Approach.

For this, a conceptual plan was created and the selection of texts that could be discussed and deepened by the component, (Fig. 1). Always seeking dialogue, the activities were presented in class and negotiated with the students following the line of proposition, problem solving and workshop development. The idea of a proposal organized in this way, aims to enable students a meaningful experience in which the subject becomes protagonist of their own learning process and has a broader view of knowledge.

The formation of the subject involves a complex set of dimensions that has in its centrality the proper action of the subject, a way of enabling those who wish to constitute to educate and to develop themselves, to reach emancipation, the full condition of autonomy. The human being, as manager of his own life, of socially organizing himself,

It can build its way of life on the basis of freedom of will, autonomy to organize modes of existence and responsibility for the direction of its actions. This characteristic of the human being is the foundation of the formation of the ethical subject. (Rodrigues, 2001, p. 232).

Formation in this perspective must be the obligatory direction, to which educational practices that aim to form autonomous subjects committed to ethics, the transformation of themselves and of society must permeate. Education through transformative practices in which the subject learns to build and rebuild his or her identity is an essential foundation for the full exercise of the right to citizenship, effective social participation, and awareness of their civil rights and duties social, political, economic and ethical. 
Fig.1 Planning and feedback of activities - Production of meanings. Source: Author's Construction.

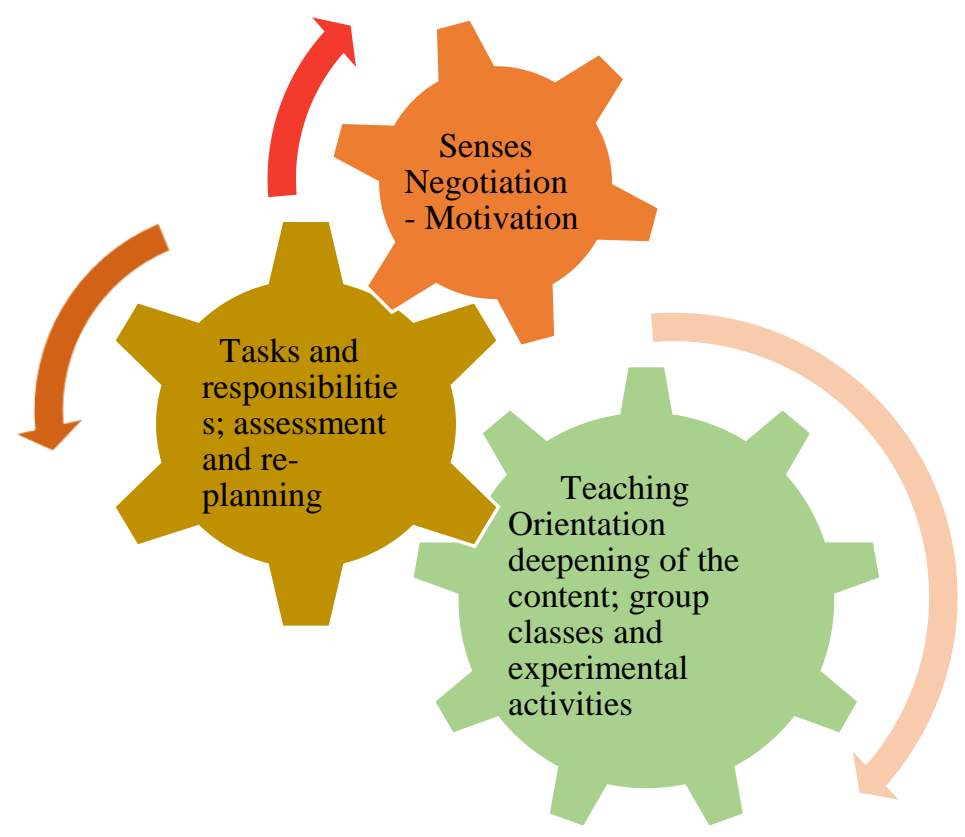

The activities were planned collaboratively with didactic strategies and production of knowledge that develops in small groups, focusing on the organization and the stimulus of learning, the proposition of problems. It is thus an open pedagogical inspiration for the development of certain skills such as learning to think, to argue, to write and to critically select information, as well as to learn to cooperate and work in teams.

It was in this conception that the use of the Problem Based Approach (PBA) was used, coupled with the holding of workshops as a pedagogical strategy capable of helping the resolution of problem situations and discussing the subjects of the discipline through a bias of interdisciplinarity.

The work was built in partnership with the teacher and students and widely debated in a process of constant feedback of the activities developed in the classroom, based on the theoretical support offered by the curriculum component, with the conviction that interdisciplinary work would promote a possibility of broader vision and of the whole pedagogical field. Thus, it was possible to build the partnership, dialoguing about the constituent elements of the component and the themes involved to find points of connection and tension that could allow the interlocution between component, content and within the scope of the teacher / student dialectic.

In this spectrum, formation as a field of knowledge reveals the need for understanding knowledge in all its nuances, the contribution of scientific knowledge to emancipatory educational processes is not enough, it is necessary to attribute the attributes of ethics, politics, culture, etc. as well put by Morin (2000). If knowledge is an instrument of power, it is also of resistance and shifts the subject to and from new realities. 
Epistemological, cultural, political knowledge represents a link in the understanding of formation as a field of knowledge and research. Understanding knowledge in its multiple dimensions helps to understand the complexity of the field of formation and the different influences that intertwine it.

\section{ANALYSIS AND REFLECTION ON DATA}

The formation of teachers of Natural Sciences as a field of knowledge and research needs a contribution of theoretical references that support the multiplicity and complexity of phenomena involving the teaching and learning processes; it must be thought of from the point of view of complexity and multireferentiality. In this line of thought, it is essential to develop an investigative training, focused on a reflective critical view of teaching that is anchored in a knowledge dimension that integrates Science, Technology, Society and Environment.

The influence that science and technology have on our actions, our way of being and being in the world, is undeniable. Bernard and Crommelinck (1992, apud Santos and Mortimer, 2012) speak of a way of autonomization of scientific reason that resulted in the development of a true faith in man, in science, in reason, in short, a faith in progress. For Japiassu (1999) the idea of a science seen as capable of answering all questions, that the problems of humanity could be solved by science generated an uncritical view of science and technology, bringing consequences for science education curricula. . One of them was the claim that the curricula oriented by this aspect had to train small scientists using laboratory activities.

This promise to train future scientists has been misrepresented with the teaching-learning practices themselves, in which the idea of laboratory activities per se was not enough to make students active subjects in the teaching-learning process.

In this perspective, it is necessary to think the investigative and reflective teaching practice by a line of thought of problematization and (re) construction of reflection, research and teaching, which enables (re) thinking and (re) building complexity of life through the investigative teaching praxis. Therefore, it is necessary to invest in an investigative and reflective teacher education that finds foundations in the theories of complexity, multi-referentiality and ecoformation. Imbernón (1994) corroborates this idea when it explains that the development of the ability to reflect on the teaching practice itself represents the fundamental axis of the teacher education curriculum and aims to learn to interpret understand and reflect on social reality and teaching.

A training concerned with the dimension of being includes valuing the teaching profession, enabling appropriate conditions for carrying out their work activities and investing in their 
professionalism, as proposed by Borges (2014), understanding how teachers build and develop professional knowledge and skills from your work experiences.

Complex thinking offers possibilities to construct other conceptions of science and education, presents ways to overcome the limitations arising from a linear model of science, technology and society. Thus, undertaking a new vision of training can help to overcome the difficulties of teaching and learning processes, social inequalities, the exclusion of people in the participation of their rights and duties.

On the other hand, there is the understanding that contemporary education suffers the effects of a neoliberal and conservative discourse that somehow ends up imprinting on the teaching work, a certain framework of understanding and action of teachers.

A self-directed learning perspective, in which problems represent the means for developing problem-solving skills, when proposed, exposes students to motivating situations and prepares them for the working world. The Problem Based Approach (PBA) is one of the possible ways, in a critical and reflexive bias, to think about teacher education and can assign new meanings to educational processes.

As a strategy for action, the workshop holds and accumulates deep and complex discussions drawn from philosophy, sociology and psychology, and with them establishes an intense dialectical relationship of confrontation and contradiction. Its purpose is to give concrete and constant answers to the teacher's anxieties, such as: How to teach? How to make the student build knowledge, not just memorize already established standards? How to make class more enjoyable, less boring for students?

The conversation wheels always occurred after the planning of group activities. Resumption in the larger group often resulted in the correction of the replanning route to define new directions. Thus, the workshops were organized from the proposition of a problem whose resolution involved at least two to three areas of knowledge and could answer the pedagogical questions posed in the paragraph above. Most students (15) evaluated them as an efficient strategy for teaching aids to teachers, a different and innovative way of solving problems and working content in the classroom. See some examples in Figure 2. 
Fig. 2 Student testimony. Source: Author's Construction.
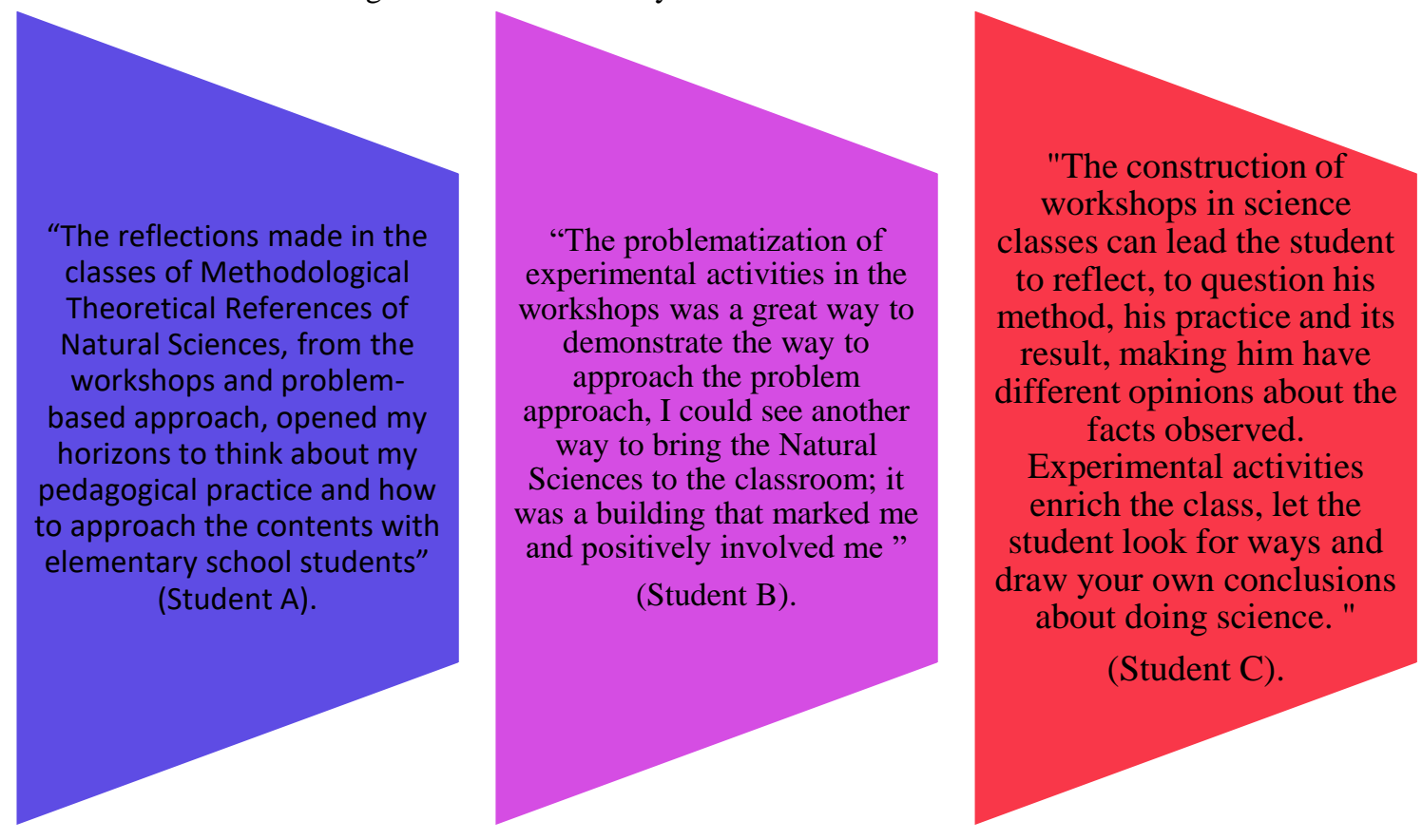

But for some students, the experience with the PBA and the workshops was quite challenging, generating some insecurity and discomfort because they had not yet addressed the contents in this view. "I had no idea that this form of content could make our classes so dynamic and arouse our interest. On the other hand, I felt very insecure and many times without knowing how to deal with the investigative approach to content, I had no laboratory activities during my life school” (Student D).

Others (7) understood that problem proposition and experimental activities stimulate students to participate, develop logical reasoning skills and build their own knowledge, but had difficulty associating the problem they were proposing to the workshop as a learning strategy based on PBA (Fig.3). 
Fig. 2 Student testimony. Source: Author's Construction.

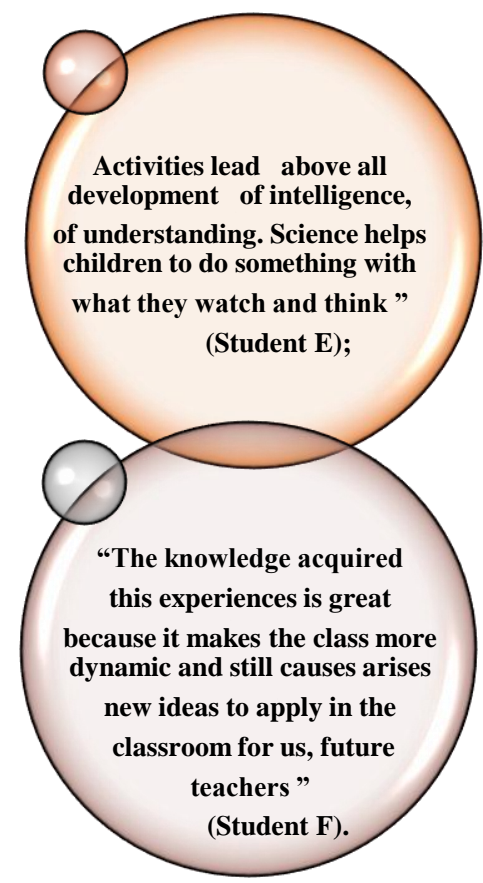

Even with these questions presented by some students, it was found that there was an understanding on the part of respondents in general, that the work proposal occurred cooperatively, and the themes of the workshops were discussed in an interdisciplinary perspective.

\section{FINAL CONSIDERATIONS.}

Training is a broad, dynamic and complex process that involves the participation of all and requires from the teacher not only mastery of pedagogical and specific content of the area, but an overview of reality that surrounds the awareness and responsibility of its role as a trainer of subjects inserted in a context that need to develop criticality, understanding their reality and becoming emancipated individuals.

Experimental activities were instrumental in stimulating research, critical thinking and the construction of knowledge in an innovative way and orienting learning in a critical and reflective way. Of the 22 participants, 15 evaluated the workshops and the use of PBA as an efficient strategy in teaching aid to the teacher; 7 did not associate the proposition and solution of the problem with PBL. There was an understanding on the part of the respondents that the work proposal occurred in a cooperative way and the workshop themes were discussed from an interdisciplinary perspective. It is inferred, then, that it is possible to add positive aspects to the development of competences, by conducting workshops and using the PBA.

The PBA combined with the conduction of Pedagogical Workshops adds positive aspects to the development of competences, and consequently to the construction of knowledge individually and collectively. Innovation in higher education is still a contemporary challenge. Therefore, the methodology 
used can offer significant potential to help teachers overcome obsolete pedagogical practices and reflect on the real meaning of their pedagogical actions. This allows them, from the appropriation of methodological theoretical contributions, to build and reconstruct knowledge, consciously and intentionally, generating more qualified teaching and learning processes.

Therefore, it is necessary to think of formation in a dimension of being, in an integrated and integrative way, which goes beyond the walls of disciplinarity, with the focus on complexity, multireferentiality, in the belief that they can contribute significantly to the formation of teachers and to the diffusion of knowledge in Natural Sciences. 


\section{REFERENCES}

ANJOS, Marineuza Matos. (2017). As oficinas como estratégia pedagógica para resolução de problemas: uma experiência no ensino superior. Teaching Day'17 a investigação no ensino-aprendizagem, práticas de articulação, $6^{\text {a }}$ edição. Universidade de Aveiro, Portugal.

ARDOINO, Jacques. ( 1998). Abordagem multirreferencial (plural) das situações educativas e formativas.: In: Barbosa, J. Multirreferencialidade nas ciências e na educação. São Paulo: Editora da UFScar. pp. 24-41.

BARBOSA, Joaquim Gonçalves, (2012). Uma escola multirreferencia: a difícil arte de se autorizar, o pensamento plural de Jacques Ardoino e a educação. Belo Horizonte: Autentica Editora. (Coleção Pensadores \& Educação). In: MACEDO, R.; BARBOSA, J. G; BORBA, S. (orgs). (2012). Jaques Ardoino \& a educcação.--Belo Horizonte: Autentica Editora.-- (Coleção Pensadores \& Educação).

BERGER, Guy. (2012). A multirreferencialidade na universidade de Paris Vicennes à Saint-Denis: o pensamento e a práxis de Jacques Ardoino. Belo Horizonte: Autentica Editora,. (Coleção Pensadores \& Educação). In: MACEDO, R,S , BARBOSA, J, G \& BORBA, S (Orgs). (2012). Jacques Ardoino e a educação.

BORGES, Maria Célia. (2013). Formação de professores: desafios históricos, políticos e práticos. São Paulo: Paulus.

IMBERNÓN, Francisco. (1994). La formación del profesorado. Espanha: Paidós.

JAPIASSU, Hilton. (1999). Um desafio à educação: repensar a pedagogia científica. São Paulo: Letras \& Letras.

LOPEZ, Ángela del Valle \& FERNADEZ, Núria Villa. (2015). Aprendizaje basado em problemas: una propuesta metodológica com futuro. In: El aprendizaje basada em problemas: una propuesta metodológica en educación superior. ECRIBANO, Alicia \& DEL VALLE, Ángela (Org). Narcea, S.A. Ediciones, $3^{\mathrm{a} e d}$. Madrid, Espanha.

MORIN, Edgar. (2000). A cabeça bem-feita: repensar a reforma, repensar o pensamento. $3^{\text {a }}$ ed. Rio de Janeiro, RJ: Bertrand Brasil.

MOYA, Assunción Manzares. (2015). Sobre el aprendizaje basado em problemas. In: El aprendizaje basadao em problemas: uma propuesta metodológica en educación superior. ECRIBANO, Alicia \& DEL VALLE, Ángela (Org). Narcea, S.A. Ediciones, $3^{\mathrm{a}} \mathrm{ed}$. Madrid, Espanha.

RODRIGUES, Neidson. (2001). Educação: da formação humana à construção do sujeito ético. Educação \& Sociedade, Campinas, v. 22, n. 76, p.232-257, out. Disponível em: http://www.scielo.br/scielo. php? pid=S0101-73302001000300013\&script=sci_abstract\&tlng=pt. Acesso em: 22 set. 2019.

SANTOS, Wilson L. P. dos; MORTIMER, Eduardo Fleury. (2002). Uma análise de pressupostos teóricos da abordagem C-T-S (Ciência - Tecnologia - Sociedade) no contexto da educação brasileira. Ensaio: Pesquisa em Educação em Ciências, Belo Horizonte, v. 2, n. 2, p. 110-132. 